\title{
Onset of new, progressive crustal growth in the central Slave craton at $3.55 \mathrm{Ga}$
}

\author{
J.R. Reimink ${ }^{1 *}$, D.G. Pearson² ${ }^{2}$ S.B. Shirey ${ }^{1}$, R.W. Carlson ${ }^{1}$, J.W.F. Ketchum ${ }^{3}$
}

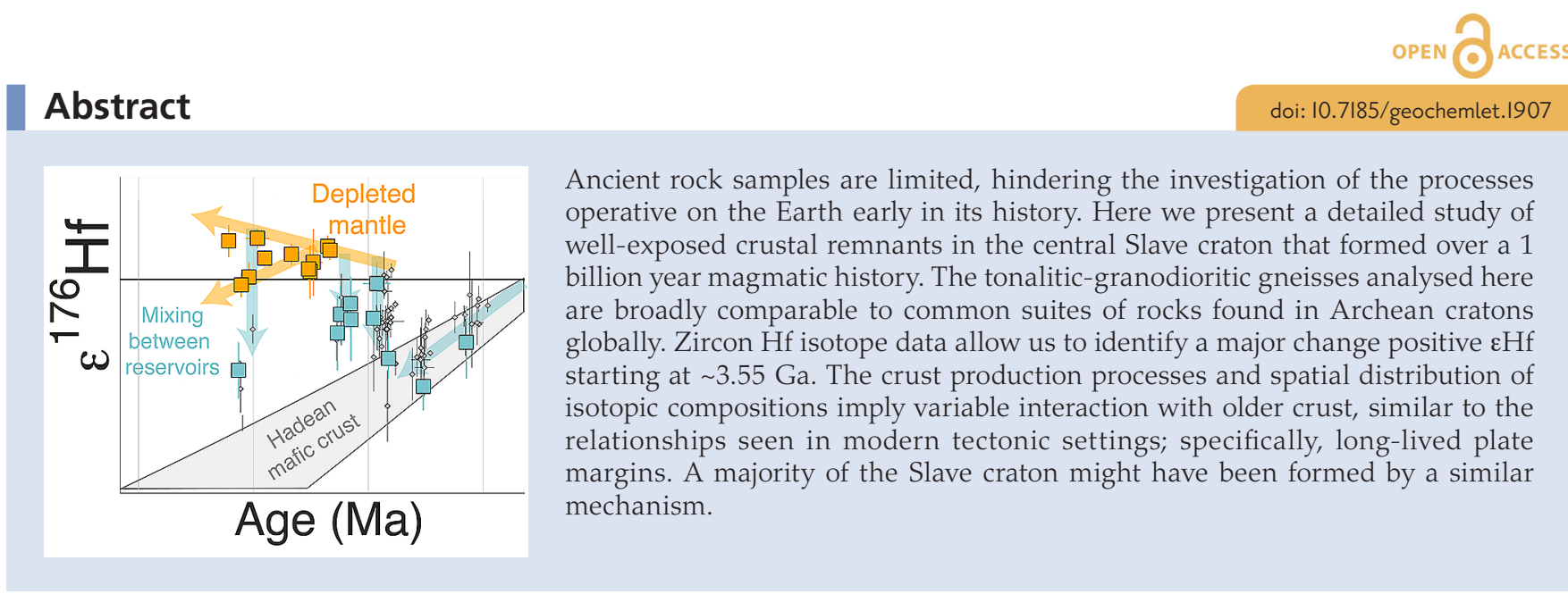

Received 1 November 2018 | Accepted 20 February 2019 | Published 28 March 2019

\section{Introduction}

The growth and preservation of Earth's continental crust is an important planetary differentiation process. The Eo- to Mesoarchean is an important era when crustal preservation was just beginning to become successful. Crust from this period is the only vestige that remains to evaluate early geodynamics, the evolution of the atmosphere and ocean chemistry, and ultimately, the origin of life. Though many recent models suggest that a large fraction of the present crust formed in the Archean (e.g., Dhuime et al., 2015), details of the timing of its extraction from the mantle and the mechanism of continental growth remain unclear, in part because of an incomplete rock record in many areas. Here we study an ancient crustal terrane that preserves an exceptionally long record of crustal production, allowing us to track the geodynamic processes of crust formation for over 1.5 Gyr.

Archean cratons are blocks of stable continental crust $>2.5$ billion years old, forming the cores of Earth's most ancient continents. The Slave craton of the Northwest Territories, Canada is an archetypal example, with extensive exposures of Meso- to Palaeoarchean rocks, making it ideally suited for tracing crust formation and reworking in the Archean.

The core of the Slave craton-the Central Slave Basement Complex (CSBC; Bleeker et al., 1999a,b) — consists of extensive exposures of basement gneiss thought to extend even farther beneath younger granitoids (Davis and Hegner, 1992; Thorpe et al., 1992; Fig. 1). Although other cratons are also endowed with basement gneiss complexes (e.g., Moyen and Martin, 2012), the Slave craton is exceptional for the age range of exposed crust within a coherent geographic area. The detailed petrologic and tectonic framework for the formation of the Acasta Gneiss Complex (AGC) from 4.02 to $3.4 \mathrm{Ga}$ (e.g., Reimink et al., 2018 and references therein) can be used to explore how the younger, more geographically expansive, CSBC is related to the AGC in the subsequent billion years of crustal evolution. The new data presented here from both younger AGC samples (3.4-2.94 Ga) as well as a suite of 3.4-2.9 Ga CSBC samples, allow direct examination of the evolution of the broader Slave craton.

\section{Geology and Geochemistry of the Slave Basement Gneisses}

The definition of the CSBC (Bleeker et al., 1999a) encompasses the zone of exposed basement gneisses in the central to south-central portion of the craton, including the Acasta Gneiss Complex. However, we refer to the CSBC and AGC independently to compare their formational mechanisms. The Acasta Gneiss Complex, on the westernmost margin of the Slave craton (Fig. 1), has received by far the most scientific interest due to the presence of the oldest known zircon-bearing

\footnotetext{
1. Department of Terrestrial Magnetism, Carnegie Institution for Science, Washington DC, 20015, USA

2. Department of Earth and Atmospheric Sciences, University of Alberta, Edmonton, AB, Canada T6G2E3

3. Northwest Territories Geological Survey, Yellowknife, NT, Canada X1A1K3

Corresponding author (email: jreimink@carnegiescience.edu)
} 


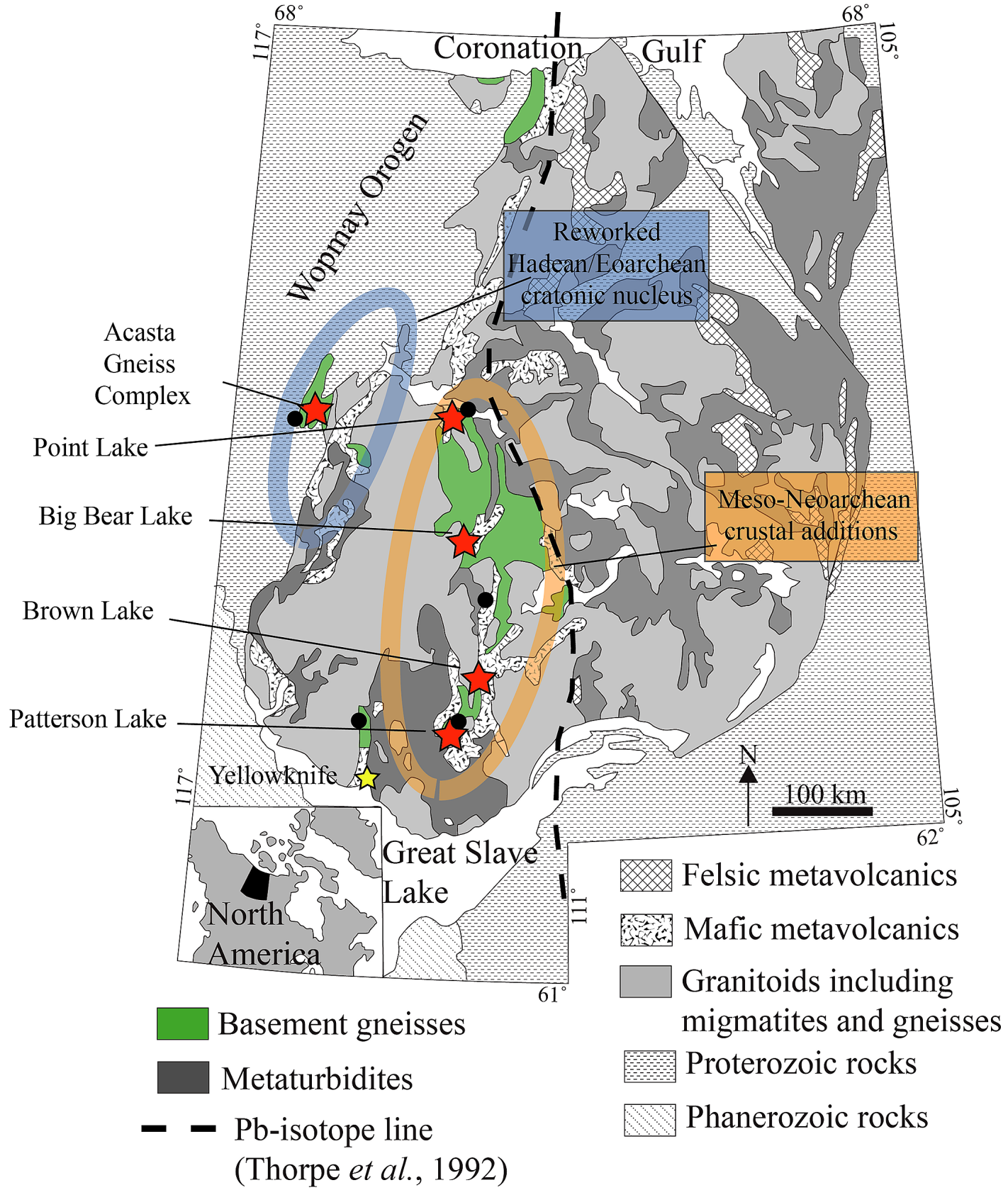

Figure 1 Geologic map of the Slave craton highlighting the major domains that contain basement gneisses. Map modified from St. Onge et al. (1988); Bleeker et al. (1999a,b). Major basement complexes are shown along with crustal province boundaries inferred from $\mathrm{Nd}$ and $\mathrm{Pb}$ isotope data (Davis and Hegner, 1992; Thorpe et al., 1992). Red stars indicate key locations sampled in this study and coloured circles are locations where detrital zircons have been analysed for their U-Pb-Hf systematics as described in Figure 3 and the Supplementary Information.

rocks on Earth (e.g., Bowring and Williams, 1999; Reimink et al., 2016a). Recent petrologic and geochemical studies have documented systematic trends in the geochemical character of AGC rocks through time (e.g., Reimink et al., 2016b; 2018), which are used here to evaluate continued crustal growth in the broader Slave craton.

Previous work on the CSBC focused on preliminary field characterisation, geochronology, and its structural evolution (e.g., Isachsen and Bowring, 1997; Bleeker et al., 1999a,b; Ketchum et al., 2004). Many of the exposed rocks in the CSBC are deformed, masking primary field relationships. Multiple magmatic pulses have been clearly defined within the Slave basement gneisses (van Breemen et al., 1992; Bleeker et al., 1999a; Sircombe et al., 2001; Ketchum et al., 2004), with major events from 4.02-2.8 Ga defined by Bleeker and Davis (1999) and summarised by Sircombe et al. (2001). Distinct magmatic pulses are evident at $\sim 3.4-3.3 \mathrm{Ga}, 3.26-3.2 \mathrm{Ga}, 3.16-3.1 \mathrm{Ga}$, 3.06-3.01 Ga, 2.99-2.93 Ga, and 2.9-2.85 Ga. This nearly continuous record of magmatism makes the CSBC an excellent natural laboratory to study crust formation mechanisms over an important period of continent formation on Earth.

\section{Results}

Sample descriptions, whole rock compositions, and U-Pb-Hf data from individual analyses can be found in the Supplementary Information, along with intra-rock sample averages (i.e. averages from all magmatic zircons within a given sample) plotted in Figure 3. 

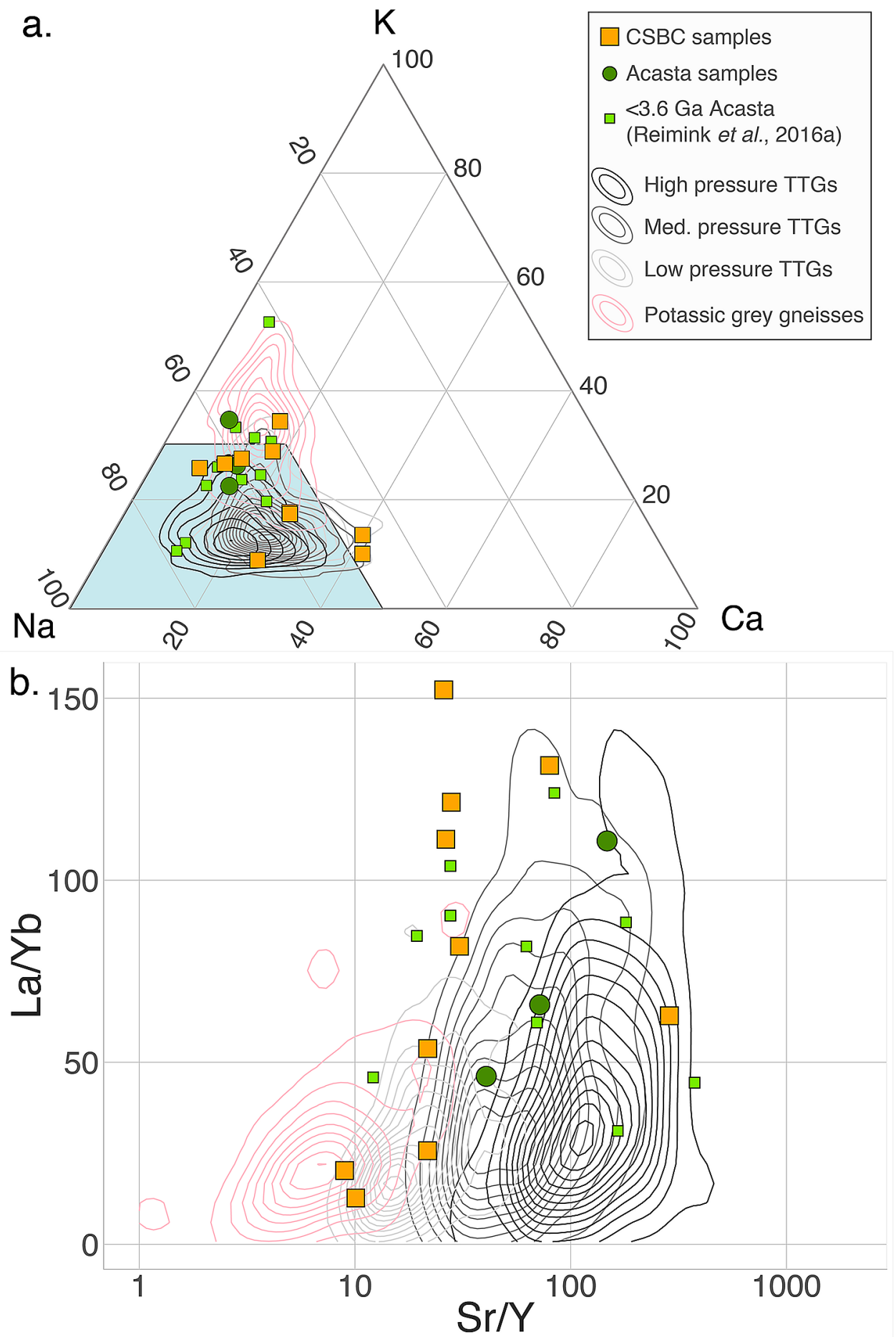

Figure 2 (a) Molar K-Na-Ca diagram. Orange squares are CSBC samples from this study. Green symbols are <3.6 Ga samples from the Acasta Gneiss Complex, small squares are samples measured by Reimink et al. (2016b) and dark green circles are samples added in this study. Contour density fields are high pressure TTGs (black), medium pressure TTGs (medium grey), low pressure TTGs (light grey), and potassic Archean grey gneisses (pink). Data used to construct these fields are taken from Moyen (2011). The blue field outlines sodic trondhjemites. (b) La/Yb versus Sr/Y for rocks from the Slave basement gneisses. Symbols as in (a).

\section{Juvenile Crustal Growth of the Slave Craton}

Most of the rocks analysed here from the CSBC have elemental compositions similar to typical Archean grey gneiss suites (Moyen and Martin, 2012) and can be classified as TTGs (tonalite-trondhjemite-granodiorites). The sodic nature of these CSBC granitoids $\left(\mathrm{Na}_{2} \mathrm{O} / \mathrm{K}_{2} \mathrm{O}\right.$ generally $\left.>1.3\right)$ and relative enrichments in the incompatible trace elements suggests a derivation by partial melting of hydrated basalt (as summarised in Moyen, 2011; Moyen and Martin, 2012). The La/Yb and Sr/Y of sodic melts typically increase with more residual garnet and a greater depth of melting. CSBC rocks have a range in La/ $\mathrm{Yb}$ and $\mathrm{Sr} / \mathrm{Y}$, but they fall within the range of Archean TTGs, typically comparable to the medium and high pressure TTGs (Fig. 2).

The Hf isotope data from AGC granitoid rocks are broadly similar to trends seen in previous Hf isotope studies of AGC zircons (e.g., Iizuka et al., 2009; Bauer et al., 2017; Fig. 3). Notably, $>3.6 \mathrm{Ga}$ zircons from the AGC have significantly negative initial $\varepsilon H f$ values that fall along an evolution line suggestive of reworking of Hadean protocrust (e.g., Bauer et 


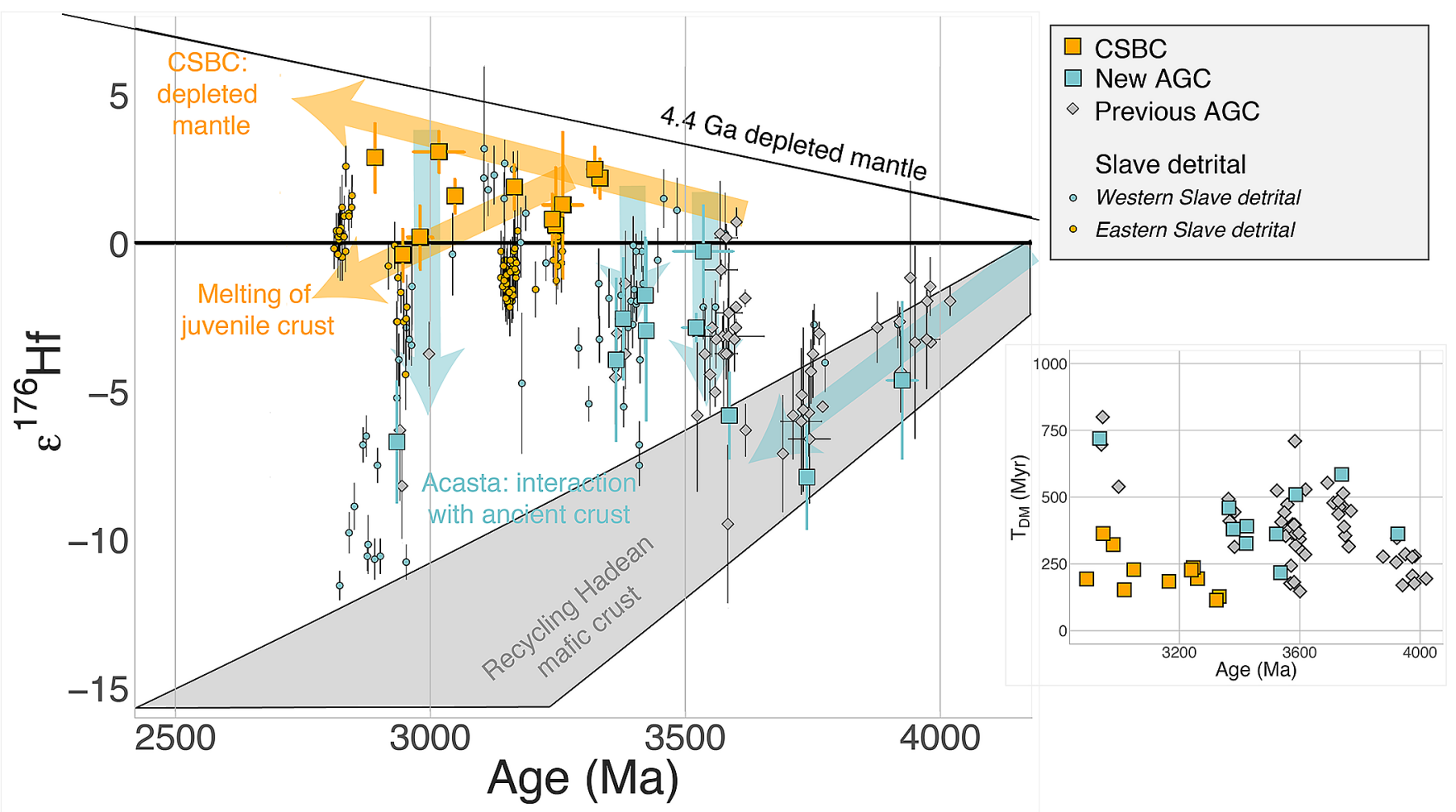

Figure 3 Zircon $\mathrm{Hf}$ isotope data from Slave basement gneisses. Orange symbols are analyses from the CSBC, blue are new analyses from the AGC, grey diamonds are a compilation of Acasta Hf isotope data (sources in the text), and small circles are single detrital zircon analyses from sediments of the Slave Craton Cover Group sequence (Pietranik et al., 2008). Note that detrital zircon analyses are grouped by sediment location (see Supplementary Information). Grey field is the evolution of Hadean mafic protocrust, while orange and blue lines show our interpretations (sloped lines for time-integrated isotope evolution, vertical lines for mixing) for systematic petrogenetic differences between the two portions of the Slave basement gneisses. The Archean depleted mantle evolution line shown here is the connector line between a chondritic source at $4.4 \mathrm{Ga}$ and modern MORB $\varepsilon \mathrm{Hf}$ values of +17 . Calculated with respect to this model evolution for the depleted mantle, the inset shows the maximum crustal residence times (depleted mantle model ages calculated using a source ${ }^{176} \mathrm{Lu} /{ }^{177} \mathrm{Hf}$ of 0.015 , and then subtracting the U-Pb crystallisation age from this model age) for all Slave craton $\mathrm{Hf}$ isotope data. The transition from long to short crustal residence times occurs at $3.6 \mathrm{Ga}$.

al., 2017). In contrast, younger AGC granitoids that formed between 2.95 and $3.6 \mathrm{Ga}$ have higher $\varepsilon \mathrm{Hf}$ that is clearly offset from the Hadean protocrust reworking trend (Fig. 3) suggesting that these new crustal additions involved mixing between recently-mantle-derived crustal magmas and Hadean protocrust. Magmatic assimilation of ancient crust is the preferred mechanism for isotopic mixing in this case, supported by the presence of $>3.6 \mathrm{Ga}$ xenocrystic zircons found in $3.6 \mathrm{Ga}$ magmatic rocks (e.g., Iizuka et al., 2007; Reimink et al., 2016a).

The CSBC represents the major volume of the preserved Slave cratonic nucleus. Zircons from CSBC granitoids have positive initial $\varepsilon H f$ values, distinct from AGC rocks of similar age, indicating derivation from a source that evolved with higher-than-chondritic Lu/Hf. Our Hf isotope data suggest that these CSBC granitoids represent largely new crustal additions from the mantle and did not interact with $>3.6 \mathrm{Ga}$ material to any significant extent. We interpret negative $\varepsilon \mathrm{Hf}$ values within the CSBC to be due to internal reworking of older (ca. $3.35 \mathrm{Ga})$ silicic material, however, there is no indication within the CSBC data that much older, AGC-aged rocks, were present in that area. This differs significantly from the original interpretation of a previous study (Pietranik et al., 2008) that used detrital zircons from the sedimentary sequence deposited directly on the CSBC rocks. These detrital zircon grain $\mathrm{U}-\mathrm{Pb}-\mathrm{Hf}$ data were grouped from across the entire craton, lumping terranes together to infer episodic mafic crust extraction and protracted reworking (Pietranik et al., 2008). However, when the detrital zircon data are subdivided by terranes, the U-Pb-Hf data from these grains matches our new data well, supporting our interpretations (Figs. 3, S-1).
Isotopic Structure of the Slave Craton and the Transition to Short-lived Protocrust

The new AGC data are consistent with a previous model suggesting that $>3.7$ Ga rocks in the AGC were derived by melting of long-lived Hadean protocrust (e.g., Iizuka et al., 2009; Guitreau et al., 2014; Bauer et al., 2017; Reimink et al., 2018), which has been documented in several other ancient gneiss localities (e.g., Kemp et al., 2010; O’Neil et al., 2013). Rocks of the AGC that were produced from melts of this protocrust have major element compositions representative of shallow-level differentiation, both by fractional crystallisation and shallow-level melting (e.g., Reimink et al., 2014, 2016a,b, 2018). In contrast, the positive initial $\varepsilon H f$ values in the CSBC show that this geographically dominant swath of evolved crust was not derived by the remelting of long-lived Hadean mafic crust. Instead, the vast majority of the pre-2.9 Ga Slave craton was progressively, and rapidly, derived from mantle sources throughout the Mesoarchean without significant interaction with older crust. What isotopic variation is present can be easily explained by a small amount of assimilation of the older generation of CSBC crust (ca. 3.3-3.4 Ga).

Prevailing models for Archean TTG petrogenesis (e.g., Moyen and Martin, 2012) dictate that rocks of these compositions were not direct mantle melts but instead formed by partial melting of mantle-derived basalts, thus requiring some, albeit short, intervening crustal residence history in the isotopic evolution from their mantle source. Maximum crustal residence times can be estimated by calculating the difference between the age of the rock and the depleted mantle model ages for the $\mathrm{Hf}$ isotope data (using an average $\mathrm{Lu} / \mathrm{Hf}$ ratio for 
mafic crust and a model depleted reservoir). These residence times depend on the assumed Hf isotope evolution of both the crustal precursor and the depleted mantle, so they should be considered relative values rather than absolute time intervals. Nevertheless, the relatively brief protocrustal residence prior to melting to produce the CSBC TTGs is distinctly different from the $>400$ Myr protocrustal residence times documented in several Hadean-Eoarchean crustal blocks described above, including the AGC (Fig. 3, inset). The relatively rapid reworking of mafic protocrust in the CSBC is similar to that seen in parts of many Neoarchean terranes and the modern plate tectonics dominated Earth.

\section{Implications for Craton Formation Mechanisms}

Magmatic events occurred in both the CSBC and the AGC during similar times (3.4-3.3 Ga and 2.95 Ga), and produced rocks with similar elemental compositions (Fig. 2). The Hf isotope distinction between these two crustal blocks, where rocks from the CSBC have higher initial $\mathrm{eHf}$ values than their AGC counterparts (Fig. 3), is important for evaluating crustal production mechanisms. In the AGC area, Hadean-Eoarchean crust was involved in the formation of Mesoarchean granitoids whereas CSBC rocks were mostly derived from newly formed sources whose isotopic compositions were similar to some models for Archean depleted mantle compositions (i.e. positive $\varepsilon H f$ values).

Several Archean granite-greenstone terranes appear to have been generated by some form of so-called 'vertical tectonics' either by a density inversion formed by erupted mafic rocks lying on top of partially molten, granitic, mid-crust (e.g., Collins et al., 1998), or by melting at the base of a thickened oceanic plateau (e.g., Smithies et al., 2003). When mafic rocks are erupted through pre-existing continental rocks, as in the gravitational instability model, there is typically a significant amount of crustal assimilation and the mafic rocks record this in their isotopic systematics. Yet, the CSBC felsic rocks that were produced over a $\sim 500 \mathrm{Myr}$ interval show initial Hf isotopic compositions paralleling the isotopic evolution of a modelled depleted mantle that began forming at $4.4 \mathrm{Ga}$. Though the exact Hf isotope evolution of the depleted mantle is uncertain, there is no indication in the younger TTGs for involvement of significantly older crustal basement, either by long-term storage of mafic crust or by assimilation of pre-existing crustal sections in the CSBC. In contrast, crustal residence times recorded in areas where melting at the base of an oceanic plateau is invoked, such as the Pilbara craton, extend up to a billion years, and crust formed in this manner has depleted mantle model ages reflecting this ancient parentage (e.g., Smithies et al., 2003). This feature is notably absent in all of the CSBC Hf isotope dataset.

The isotopic differences and spatial extent of newly created crustal rocks between the CSBC and AGC areas are similar to those found in modern plate margin provinces where new crust is being created adjacent to, but spatially distinct from, older continental crust. On the modern Earth, major zones of continental growth occur at the edge of pre-existing continental crust. When subduction zones are developed along continental margins, the new magmas produced in these settings often show isotopic signatures that systematically vary from primitive mantle-like near the subduction zone to more isotopically evolved compositions toward the continental mass (e.g., the ${ }^{87} \mathrm{Sr} /{ }^{86} \mathrm{Sr}=0.706$ line in the Western US; Kistler and Peterman, 1973). Indeed, the CSBC rocks have trace element compositions compatible with a subduction zone (e.g., enrichment in large-ion lithophile elements and depletion in high field strength elements; Fig. S-2), and such signatures have been used to argue for evidence of plate margin settings in the Archean, though this is far from resolved (e.g., Moyen et al., 2012). In fact, this subduction-accretion process was invoked to explain isotopic trends in $\sim 2.6$ Ga granites in the Slave craton (Davis and Hegner, 1992) that mimic the trends of the 3.4-2.9 Ga Slave craton gneisses.

By $3.7 \mathrm{Ga}$, the Acasta area had stabilised as an evolved continental nucleus produced by reprocessing of Hadeanaged protocrust (e.g., Reimink et al., 2016b; 2018). At 3.55 Ga new crustal rocks were created in the AGC from a source containing juvenile, mantle-derived input. The spectrum of initial $\varepsilon \mathrm{Hf}$ in these rocks is interpreted to be due to variable interaction between juvenile magmas and the rocks of the ancient continental nucleus via assimilation. This process clearly occurred as older zircons occur as xenocrysts in $\sim 3.6 \mathrm{Ga}$ samples. We also infer that assimilation generated the isotopic spread in the AGC at 3.4 and $2.95 \mathrm{Ga}$. During this same time, the majority of the CSBC crust was being constructed entirely from mantle sources, i.e. sources with no evidence of significant crustal prehistory. Because no substantially older crustal nucleus existed in the CSBC, the magmas that built this crust retained the depleted mantle isotopic signature. Furthermore, throughout this process, even the latest magmatic rocks were not assimilating and interacting with previously formed CSBC basement, suggesting lateral, rather than vertical, growth of the crust. Processes akin to modern subduction provide one mechanism to generate these isotopic and petrologic characteristics of the Slave basement gneisses, and indeed, models have suggested that subduction can initiate on the margins of plume-derived magmatic systems (e.g., Geyra et al., 2015). This is perhaps the mechanism that generated the 3.75-3.6 Ga transition in the AGC. Similar geodynamic changes have been invoked for other locations on Earth at different times (e.g., Næraa et al., 2012), suggesting that such transitions were not contemporaneous global changes, but occurred in different places at different times. Nevertheless, the CSBC represents a clear example of Mesoarchean crust that was formed by addition of new, juvenile, mass to the continent.

\section{Acknowledgements}

We thank Chiranjeeb Sarkar for assistance with the U-Pb-Hf analyses, Scott Cairns and the Northwest Territories Geological Survey office for field support, and Tom Chacko, Ann Bauer, and Josh Davies, for valuable discussions. We also thank Matt Scott and Michael Long for assistance in the field. Thoughtful reviews by Tony Kemp and one anonymous reviewer substantially improved this manuscript. We thank Helen Williams for editorial handling.

Editor: Helen Williams

\section{Additional Information}

Supplementary Information accompanies this letter at http:// www.geochemicalperspectivesletters.org/article1907.

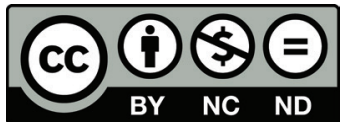

This work is distributed under the Creative Commons Attribution Non-Commercial No-Derivatives 4.0 License, which permits unrestricted distribution provided the original author and source are credited. The material may not be adapted (remixed, transformed or built upon) or used for commercial purposes without 
written permission from the author. Additional information is available at http://www.geochemicalperspectivesletters.org/ copyright-and-permissions

Cite this letter as: Reimink, J.R., Pearson, D.G., Shirey, S.B., Carlson, R.W., Ketchum, J.W.F. (2019) Onset of new, progressive crustal growth in the central Slave craton at 3.55 Ga. Geochem. Persp. Let. 10, 8-13.

\section{References}

Bauer, A.M., Fisher, C.M., Vervoort, J.D., Bowring, S.A. (2017) Coupled zircon $\mathrm{Lu}-\mathrm{Hf}$ and $\mathrm{U}-\mathrm{Pb}$ isotopic analyses of the oldest terrestrial crust, the $>4.03 \mathrm{Ga}$ Acasta Gneiss Complex. Earth and Planetary Science Letters $458,37-48$

BleEKeR, W., DAVIS, W.J. (1999) The 1991-1996 NATMAP Slave Province Project: Introduction. Canadian Journal of Earth Sciences 36, 1033-1042.

Bleeker, W., Ketchum, J.W., DAvis, W.J. (1999a) The Central Slave Basement Complex, Part II: age and tectonic significance of high-strain zones along the basement-cover contact. Canadian Journal of Earth Sciences 36, 1111-1130

BleEKer, W., Ketchum, J.W., JacKson, V.A., Villeneuve, M.E. (1999b) The Central Slave Basement Complex, Part I: its structural topology and autochthonous cover. Canadian Journal of Earth Sciences 36, 1083-1109.

Bowring, S.A., Williams, I.S. (1999) Priscoan (4.00-4.03 Ga) orthogneisses from northwestern Canada. Contributions to Mineralogy and Petrology 134, 3-16

Coldins, W.J., Van KranendonK, M.J., Teyssier, C. (1998) Partial convective overturn of Archaean crust in the east Pilbara Craton, Wester Australia: driving mechanisms and tectonic implications. Journal of Structural Geology 20, 1405-1424.

DAVIS, W.J., HegneR, E. (1992) Neodymium isotopic evidence for the tectonic assembly of Late Archean crust in the Slave Province, northwest Canada. Contributions to Mineralogy and Petrology 111, 493-504.

Dhuime, B., Wuestefeld, A., HaWkesworth, C.J. (2015) Emergence of modern continental crust about 3 billion years ago. Nature Geoscience 8, 552-555.

Guitreau, M., Blichert-Toft, J., Mojzsis, S.J., Roth, A.S.G., Bourdon, B., Cates, N.L., BleEKeR, W. (2014) Lu-Hf isotope systematics of the Hadean-Eoarchean Acasta Gneiss Complex (Northwest Territories, Canada). Geochimica et Cosmochimica Acta 135, 251-269.

Iizuka, T., Komiya, T., Ueno, Y., KatAyama, I., Uehara, Y., Maruyama, S., HiRATA, T., JOHnson, S.P., DunkLeY, D.J. (2007) Geology and zircon geochronology of the Acasta Gneiss Complex, northwestern Canada: New constraints on its tectonothermal history. Precambrian Research 153, 179-208, doi: 10.1016/j.precamres.2006.11.017.

IIZUKa, T., KOMIYA, T., JOHNSON, S.P., KON, Y., MARUYAMA, S., Hirata, T. (2009) Reworking of Hadean crust in the Acasta gneisses, northwestern Canada: Evidence from in-situ Lu-Hf isotope analysis of zircon. Chemical Geology 259, 230-239.

IsACHSEN, C.E., Bowring, S.A. (1997) The Bell Lake group and Anton Complex: a basement - cover sequence beneath the Archean Yellowknife greenstone belt revealed and implicated in greenstone belt formation. Canadian Journal of Earth Sciences 34, 169-189.

Kemp, A.I.S., Wilde, S.A., HaWkesworth, C.J., COATH, C.D., Nemchin, A., Pidgeon, R.T., Vervoort, J.D., DuFrane, S.A. (2010) Hadean crustal evolution revisited: New constraints from $\mathrm{Pb}-\mathrm{Hf}$ isotope systematics of the Jack Hills zircons. Earth and Planetary Science Letters 296, 45-56.

Ketchum, J., Bleeker, W., Stern, R.A. (2004) Evolution of an Archean basement complex and its autochthonous cover, southern Slave Province, Canada. Precambrian Research 135, 149-176.

KistLeR, R.W., Peterman, Z.E. (1973) Variations in Sr, Rb, K, Na, and Initial Sr87/Sr86 in Mesozoic Granitic Rocks and Intruded Wall Rocks in Central California. Geological Society of America Bulletin 84, 3489-3512.

MOYEN, J.-F. (2011) The composite Archaean grey gneisses: Petrological significance, and evidence for a non-unique tectonic setting for Archaean crustal growth. Lithos 123, 21-36.

Moyen, J.-F., MARTIN, H. (2012) Forty years of TTG research. Lithos 148 312-336.

NÆraA, T., Scherstén, A., Rosing, M.T., Kemp, A.I.S., Hoffmann, J.E. KoKfelt, T.F., Whitehouse, M.J. (2012) Hafnium isotope evidence for a transition in the dynamics of continental growth $3.2 \mathrm{Gyr}$ ago. Nature 485, 627-630.
O’Neil, J., Boyet, M., Carlson, R.W., Paquette, J.-L. (2013) Half a billion years of reworking of Hadean mafic crust to produce the Nuvvuagittuq Eoarchean felsic crust. Earth and Planetary Science Letters 379, 13-25.

Pietranik, A.B., Hawkesworth, C.J., Storey, C.D., Kemp, A.I.S., SirCOMbe, K.N., Whitehouse, M.J., BlEeKER, W. (2008) Episodic, mafic crust formation from 4.5 to $2.8 \mathrm{Ga}$ : New evidence from detrital zircons, Slave craton, Canada. Geology 36, 875-878.

Reimink, J.R., Chacko, T., Stern, R.A., Heaman, L.M. (2014) Earth's earliest evolved crust generated in an Iceland-like setting. Nature Geoscience 7 529-533.

ReiminK, J.R., CHACKo, T., Stern, R.A., HeAman, L.M. (2016a) The birth of a cratonic nucleus: lithogeochemical evolution of the 4.02-2.94 Ga Acasta Gneiss Complex. Precambrian Research 281, 453-472.

Reimink, J.R., Davies, J.H.F.L., Chacko, T., Stern, R.A., Heaman, L.M., Sarkar, C., Schaltegger, U., Creaser, R.A., Pearson, D.G. (2016b) No evidence for Hadean continental crust within Earth's oldest evolved rock unit. Nature Geoscience 9, 777-780.

Reimink, J.R., Chacko, T., Carlson, R.W., Shirey, S.B., LiU, J., Stern, R.A., Bauer, A.M., Pearson, D.G., Heaman, L.M. (2018) Petrogenesis and tectonics of the Acasta Gneiss Complex derived from integrated petrology and ${ }^{142} \mathrm{Nd}$ and ${ }^{182} \mathrm{~W}$ extinct nuclide-geochemistry. Earth and Planetary Science Letters 494, 12-22.

SiRCOMBE, K.N., BleEKER, W., STERN, R.A. (2001) Detrital zircon geochronology and grain-size analysis of a 2800 Ma Mesoarchean proto-cratonic cover succession, Slave Province, Canada. Earth and Planetary Science Letters 189, 207-220.

Smithies, R.H., Champion, D.C., CASSidy, K.F. (2003) Formation of Earth's early Archaean continental crust. Precambrian Research 127, 89-101.

St. Onge, M.R., King, J.E., Lalonde, A.E. (1988) Geology, East - Central Wopmay Orogen, District of Mackenzie, Northwest Territories. Geological Survey of Canada, Open File 1923. doi: 10.4095/130452.

Thorpe, R.I., Cumming, G.L., Mortensen, J.K. (1992) A Significant Pb Isotope Boundary in the Slave Province and Its Probable Relation To Ancient Basement in the western Slave Province. Geological Survey of Canada, Open File 2484, 179-184, doi:10.4095/133349.

van Breemen, O., Davis, W.J., King, J.E. (1992) Temporal distribution of granitoid plutonic rocks in the Archean Slave Province, northwest Canadian Shield. Canadian Journal of Earth Sciences 29, 2186-2199. 